und Bedingungen dafür, ein wachsendes Interesse auslösen, aber leider war dem nicht so. Dies lag sicherlich zum einen an der Fülle (der Überfülle, wie viele Teilnehmer beklagten) der parallel veranstalteten Sektionen, aber wohl auch zum anderen daran, daß die „östliche Dimension“ der Wissenschaftsgeschichtsschreibung droht, marginal zu werden. In Moskau existiert das ,Institut für Geschichte der Naturwissenschaften und Technik“ bei der Russischen Akademie der Wissenschaften zwar immer noch, aber die dort veröffentlichten Publikationen können schwerer denn je den Weg nach Westeuropa finden, und seine Mitarbeiter befinden sich seit Oktober (1996) in einem „verordneten Urlaub“, d.h. sie sitzen in ihren - meist sehr kleinen - Wohnungen und ohne Gehalt. Dabei könnten die Erforschung des Wissenstransfers, die Vermittlung als gelebter Erfahrung von Beziehungen der internationalen „scientific community“, auch die auf der Veranstaltung vorgesteliten Beispiele ermutigen, ermutigen zur weiteren Erforschung dieser Beziehungen und zum aktuellen Gestalten derselben.

Annette Vogt (Berlin)

\title{
Call for Papers. American Association for the History of Medicine, 1998 Annual Meeting.
}

The 1998 meeting will be held 7-10 May 1998 in Toronto, Ontario, Canada. Any person interested in presenting a paper at this meeting is invited to submit an abstract (one original and 7 copies) to the Chair of the Program Committee: John Harley Warner, Section of the History of Medicine, Yale University School of Medicine, L132 SHM, P.O. Box 208015, New Haven, CT 06520-8015.

Any subject in the history of medicine is suitable for presentation, but the paper must represent original work not already published or in press. Presentations are limited to 20 minutes. Because the Bulletin of the History of Medicine is the official journal of the AAHM, the Association encourages speakers to make their manuscripts available for consideration by the Bulletin upon request. Abstracts must be typed single-spaced on one sheet of paper, and must not exceed 350 words in length. Abstracts should include not merely a statement of a research question, but findings and conclusions sufficient to allow assessment by the committee. The following biographical information is also required: Name, title (occupation), academic degrees, preferred mailing address, work and home telephone numbers, and present institutional affiliation. Abstracts must be received by 30 September 1997. Please note that abstracts submitted by e-mail or fax will not be accepted.

As in the past, the 1998 program will include lunch-time roundtable workshops and may include poster sessions. Proposals for sessions of 3 papers may be submitted, but each abstract will be judged and accepted on its own merits. Those wishing to submit abstracts for either of these session formats should follow the instructions given above.

\section{Das Kind in Pietismus und Aufklärung}

Das Interdisziplinäre Zentrum für Pietismusforschung der Martin-Luther-Universität HalleWittenberg lädt in Verbindung mit den Franckeschen Stiftungen ein zu einem Internationalen Symposion über dieses Thema. Das Symposion, das am historischen Ort des halleschen Waisenhauses vom 12.-15.11.1997 stattfindet und für das namhafte Fachvertreter der Kindheitsforschung aus dem In- und Ausland gewonnen werden konnten, ist bewuBt interdisziplinär angelegt. Damit soll der Raum geschaffen werden, in dem es möglich ist, die vielfältigen Aspekte von Kindheit, Erziehung und Bildung im 17. und 18. Jahrhundert aus der Sicht der historischen 